\title{
Etiological Similarities Between Psychological and Physical Aggression in Intimate Relationships: A Behavioral Genetic Exploration
}

\author{
Denise A. Hines $•$ Kimberly J. Saudino
}

Published online: 1 September 2008

(C) Springer Science + Business Media, LLC 2008

Erratum to: J Fam Viol (2007) 22:121-129

DOI: $10.1007 /$ s10896-006-9059-6

In the original version of this article the order of the authors were reversed. It is now corrected on this paper. Springer regrets the error.

The online version of the original article can be found at http://dx.doi. org/10.1007/s10896-006-9059-6.

D. A. Hines $(\bowtie)$

Department of Criminal Justice,

University of Massachusetts Lowell,

870 Broadway St.,

Lowell, MA 01854, USA

e-mail: DeniseHines@uml.edu

K. J. Saudino

Department of Psychology, Boston University,

Boston, USA 